6. Konstytutsyia KNR. URL: https://chinalaw.center/constitutional_law/ (data zvernennia 9.12.2019). [in Russian]

7. Family Law in China. Yang Cheng. International Journal of Law, Policy and the Family, Volume 1, Issue 2, 1 October 1987, Pages 248-258. URL: https://doi.org/10.1093/lawfam/1.2.248 [in English]

8. Pinky Anand Family law in India: overview URL:

Acticallaw thomsonre

9. Hetman-Pavlova Y.V. Mezhdunarodnoe chastnoe pravo [International private law]: uchebnyk / Y.V. Hetman-pavlova., pererab. y dop. M., 2011. [in Russian]

10. Bürgerliches Gesetzbuch. URL:https://www.gesetze-im-internet.de/ bgb/index.html\#BJNR001950896BJNE171105140 [in German]

11. Pro mizhnarodne pryvatne pravo: Zakon Ukrainy vid 23 chervnia 2005 r. URL: https://zakon.rada.gov.ua/laws/show/2709-15 [in Ukrainian]
12. Federatyvnyi zakon Avstrii pro mizhnarodne pravo vid 15 chervnia 1978r. URL: http://iir-mp.narod.ru/subjects/iprl/austria law.htm [in Russian]

13. Kysil V.I. Mizhnarodne pryvatne pravo: pytannia kodyfikatsii [Private international law: issues of codification]. 2-e dopovn. i pererob. vyd. K.: Ukraina, 2005. [in Ukrainian]

14. Federalnyi zakon Shveitsaryy o mezhdunarodnom chastnom prave 1987 h. URL: http://pravo.hse.ru/intprilaw/doc/042901 [in Russian].

15. Hrazhdanskyi kodeks Yspanyy (Codigo Civil) URL: http://noticias.juridicas.com/base_datos/Privado/cc.html [in Spain]

16. The Re-Emergence of Family Law in Post-Mao China: Marriage, Divorce and Reproduction. Michael Palmer. The China Quarterly No. 141, Special Issue: Chinas Legal Reforms (Mar., 1995), pp. 110-134. URL: https://doi.org/10.1017/S0305741000032938 [in English]

Received: $01 / 11 / 2020$ Accepted: $20 / 11 / 2020$

L. Radchenko, PhD (Law), Associate Prof

Taras Shevchenko National University of Kyiv, Kyiv, Ukraine

\title{
LLEGAL GROUNDS FOR REGULATION FOR CERTAIN FORMS OF ARRANGEMENT FOR CHILDREN IN INTERNATIONAL FAMILY LAW
}

The article considers legal principles of regulation for relations of guardianship, care and adoption in international family law, the regulation of these forms of arranging children in law and their interpretation in the legal doctrine of certain foreign states, the definition of features and peculiarities of these concepts, the definition of relations in this field, as well as formulation of conclusions and proposals aimed at harmonization of national legislation with the law of leading foreign states.

Legal grounds for the regulation of the relations of guardianship, care and adoption in the legislation of some foreign countries shows that there are different legislative approaches to the regulation of such forms of placement of children. Historical, religious, national factors, elements of tradition and culture - all these factors significantly affect the substantive content of the essential traits of care, and adoption in different countries. At the same time, the basic provisions of such institutions are unchanged - both guardianship and adoption are intended to promote the upbringing and development of the child, to guarantee the exercise of their rights and legitimate interests, to ensure their care and custody.

Custody relations are regulated both on the basis of conflict law rules and in accordance with substantive rules of private international law. For example, in Ukraine the establishment and cancellation of custody of minors, disable persons are regulated by the personal law of the ward. The obligation of the guardian to accept guardianship is determined by the personal law of the person appointed by the guardian. The relationship between the guardian and the person under guardianship is determined by the law of the state the body of which appointed the guardian.

The regulation of relations for international adoption is subject to conflict of law rules. In Ukraine, adoption and its abolition are governed by the child's personal law and by the adopter's personal law. A person's ability to be an adopter is determined in accordance with his or her personal law. The legal consequences of adoption or termination are determined by the personal law of the adopter.

One of the areas of state activity regarding adoption should be effective monitoring and control over the processes of adoption including the participation of foreign entities as well as the further upbringing, care and observance of the rights and interests of children who have been adopted by foreigners.

Key words: form of arrangement for child, guardianship, care, adoption, international conventions, international family law, private international law.

Bulletin of Taras Shevchenko National University of Kyiv. Legal Studies, 2020; 3 (114): 50-59

УДК: 347.97

DOI: https:doi.org/10.17721/1728-2195/2020/5.115-11
ISSN 1728-2195

(C) Taras Shevchenko National University of Kyiv, Publishing center "Kyiv University", 2020

О. Угриновська, канд. юрид. наук, доц. ORCID ID: 0000-0002-3642-5903,

М. Піняшко, магістр

ORCID ID: 0000-0002-8076-6465

Львівський національний університет імені Івана Франка, Львів, Україна

\section{ПРОВАДЖЕННЯ У СПРАВАХ ПРО ВСТАНОВЛЕННЯ ФАКТУ НАРОДЖЕННЯ АБО СМЕРТІ ОСОБИ НА ТИМЧАСОВО ОКУПОВАНІЙ ТЕРИТОРІЇ УКРАЇНИ}

Досліджено функціонування судової процедури встановлення фактів народження та смерті на тимчасово окупованій території України з погляду її регламентації й ефективності. Аєторами у межах цієї роботи проаналізовано процесуальну природу провадження з установлення юридичних фактів у національному законодавстві України та здійснено аналіз законодавства іноземних держав щодо регулювання судової процедури встановлення факту народження або смерті у певний час на відповідній території. 3 урахуванням судової практики розкрито змістове наповнення ознак, за наявності яких факт народження або смерті особи на тимчасово окупованій території України підлягає встановленню у порядку окремого провадження.

Проаналізовано окремі особливості суб'єктного складу учасників справи у провадженні щодо встановлення факту народження або смерті особи на тимчасово окупованій території України. Так, звертається увага на непослідовності юридичної техніки законодавця, зокрема, щодо нерозмежування "заявників" та "осіб, які вправі звернутися із заявою". За наслідками проведеного дослідження зроблено висновок про те, які особи є суб'єктами звернення у справах про встановлення факту народження або смерті на відповідній території України.

Поряд із цим, окрему увагу приділено процесу доказування. Авторами сформульовано висновки щодо обставин, які входять до предмета доказування в аналізованій категорії справ, обов'язку доказування з урахуванням ролі й місия суду у справах окремого провадження, а також щодо оцінювання доказів і застосування "намібійського винятку" у справах про встановлення факту народження або смерті на тимчасово окупованій території України.

Ключові слова: окреме провадження, юридичний факт, тимчасово окупована територія, намібійський виняток.

ВСтУп. Загальновідомим є фракт збройної агресії 2014-2015 років з боку Російської Федерації щодо України, котра призвела до окупації території Автономної Республіки Крим, а також утворення так званих "Луган- ської та Донецької народних республік". Указані обставини зумовили ускладнення в забезпеченні правового статусу осіб, котрі проживають на тимчасово окупованій території України. Офіційною формою реагування Укра- 
їни на збройну агресію РФ стало прийняття Закону України "Про забезпечення прав і свобод громадян і правовий режим на тимчасово окупованій території України" від 15.04.2014 р., а також Постанови Верховної Ради України від 17.03.2015 р. № 254-VIII "Про визнання окремих районів, міст, селищ і сіл Донецької та Луганської областей тимчасово окупованими територіями".

Проте військовий конфллікт із державою-агресором не знімає з України обов'язку щодо забезпечення права на судовий захист осіб, що проживають або перебувають на тимчасово окупованій території, оскільки незалежно від соціальних чи політичних обставин життя таких осіб продовжується. Згідно з даними, що містяться у відкритих інформаційних джерелах на території AР Крим кількість фактів народження становила: за 2016 р. - 22995 осіб, за 2017 р. - 9810 осіб. Водночас кількість фрактів смерті на вказаній території становила: за 2016 р. - 28932 особи, за 2017 рік - 14323 особи.

У свою чергу, на території так званої "ДНР" зафріксовано:

- $\quad$ за 2016 р. - 11771 факт народження та 34833 фракти смерті;

- $\quad$ за 2017 р. - 5875 фактів народження та 17866 фактів смерті.

Зважаючи на відсутність доступної адміністративної процедури, що передбачала б алгоритм державної реєстрації фрактів народження або смерті, походження яких - тимчасово окупована територія, та з метою оптимізації процесу отримання свідоцтв про народження, про смерть для осіб, які проживають на тимчасово окупованій території України, законодавцем доповнено ЦПК України спеціальною статтею, а саме - ст. 317, що вирішувала окремі процесуальні питання спрощення провадження у справах установлення фрактів народження і смерті на тимчасово окупованій території. Окрім цього, законодавчі зміни щодо регламентації судової процедури встановлення юридичних фрактів на відповідній території спрямовані на усунення незручностей для осіб, які проживають на тимчасово окупованій території України, пов'язаних із необхідністю потрапити на підконтрольну територію держави, оскільки свідоцтво про народження або про смерть особа, яка проживає на тимчасово окупованій території України, визначеній Верховною Радою України, може отримати лише від легітимних органів влади.

Названою нормою (ст. 317 ЦПК), серед іншого, визначено коло осіб, які вправі звертатися до суду із заявою про встановлення відповідного факту; урегульовано питання територіальної юрисдикції (підсудності); закріплено положення щодо негайно виконання відповідних рішень.

Слід звернути увагу на те, що відсутність чіткої та дієвої судової процедури встановлення факту народження або смерті на тимчасово окупованій території може призвести до кола зловживань, зокрема, з метою уникнення кримінального переслідування, отримання соціальних виплат без законних підстав, торгівлі людьми тощо. Як наслідок, перед державою стоїть нелегке завдання, оскільки вона має створити доступний механізм установлення фактів на відповідній території, котрий з одного боку забезпечить належну реалізацію особистих немайнових і майнових прав осіб, а 3 іншого - унеможливить його використання для досягнення протиправної мети.

Таким чином, актуальність статті зумовлена необхідністю виявлення окремих недоліків функціонування механізму встановлення відповідних фактів на непідконтрольній території та подальшого їх усунення. У зв'язку з тим, що встановлення названих фактів відбуваєть- ся в межах окремого провадження, існує потреба у з'ясуванні юридичної природи останнього.

\section{ВИКЛАД ОСНОВНОГО МАТЕРІАЛУ}

Теоретико-правова природа провадження у справах про встановлення факту народження або смерті особи на тимчасово окупованій території України. Окреме провадження у цивільному процесі не $€$ виключно українським ноу-хау. Інші держави також забезпечують правове регулювання на національному рівні таким чином, щоб диференціювати процедуру судового розгляду з урахуванням характеру справи, виокремлюючи тим самим справи окремого провадження, зокрема стосовно встановлення юридичних фрактів, які мають значення для справи. Очевидно, що перелік юридичних фрактів, котрі можуть встановлюватися в судовому порядку в межах відповідної процедури, не є і не може бути однаковим, оскільки кожна держава визначає такі на власний розсуд. Водночас пропонується навести приклад фрактів, які можуть встановлюватися в порядку окремого провадження у вигляді своєрідного узагальнення. До таких фактів належать:

- фракт нещасного випадку (Азербайджан, Білорусь, Киргизстан, Молдова, Таджикистан, Узбекистан);

- фракт визнання батьківства (Азербайджан, Білорусь, Молдова, Таджикистан); установлення походження дітей (Франція);

- фракт політичних репресій; фракт перебування особи в концентраційних таборах (гетто) (Молдова);

- фракт поширення інформації, що утискає честь, гідність і ділову репутацію, якщо особа, від якої виходить ця інформація, невідома (Білорусь, Молдова);

- факт непереборної сили (Вірменія);

- про надання особі психіатричної допомоги в примусовому порядку (Таджикистан, Естонія);

- про обов'язкову госпіталізацію до протитуберкульозного закладу (Молдова);

- про банкрутство юридичних осіб та індивідуальних підприємців (Казахстан, Латвія);

- за скаргами на нотаріальні дії або на відмову в їх вчиненні (Азербайджан, Вірменія, Казахстан, Киргизстан, РФ, Таджикистан);

- про відновлення втраченого судового провадження (Молдова, Таджикистан);

- про реєстрацію підприємства і союзу (Грузія);

- про застосування заборони на наближення й інших аналогічних заходів для захисту прав особистості (Естонія);

- про визнання незаконними страйків або заяви про страйк (Латвія) [2].

Факт народження або смерті особи на тимчасово окупованій території України підлягатиме встановленню у судовому порядку, у таких випадках: 1) цей фракт породжує юридичні наслідки, тобто від нього залежить виникнення, зміна або припинення особистих чи майнових прав громадян; 2) чинним законодавством не передбачено іншого порядку його встановлення; 3) заявник не має іншої можливості одержати або відновити загублений чи знищений документ, який посвідчує фракт, що має юридичне значення; 4) установлення факту не пов'язується з наступним вирішенням спору про право [31].

Так, Миколаївський апеляційний суд у справі № 473/1039/19 про встановлення факту, що має юридичне значення, зауважив, що в судовому порядку встановлюють тільки такі факти, які мають юридичні наслідки і від встановлення яких залежить виникнення, зміна або припинення особистих чи майнових прав заявника [27]. Окрім цього, важливе значення має мета встановлення відповідного фракту, оскільки саме вона 
дає можливість зробити висновок, чи дійсно цей факт є юридичним і чи тягне він правові наслідки [27]. Як правило, метою встановлення відповідних фактів $є$ необхідність їхньої подальшої державної реєстрації задля отримання свідоцтва про смерть (народження) згідно $з$ чинним законодавством України [38], бажання заявника вступити у спадкові права або ж полегшити процедуру оформлення спадщини [37].

Якщо фракт, для встановлення якого особа звернулася до суду, не $є$ передумовою для зміни, виникнення чи припинення прав такої особи, то відповідна заява не підлягає розгляду в порядку окремого провадження, а тому суд повинен відмовити у відкритті провадження у справі щодо розгляду відповідної заяви [48]. 3'ясування судом уже у відкритому провадженні того, що факт, про встановлення якого звернувся заявник, жодним чином не впливає на правовий статус особи, має наслідком закриття провадження у справі [6].

Що стосується другої та третьої ознак, за наявності яких фракт може встановлюватися в межах окремого провадження, тобто у випадках, коли чинним законодавством не передбачено іншого порядку встановлення певного фракту та за відсутності іншої можливості одержати або відновити загублений чи знищений документ, який посвідчує фракт, що має юридичне значення, то яскравим прикладом є справа № 233/2929/17.

У червні 2017 р. заявник звернувся до суду із заявою про встановлення фракту його участі - як добровольця відповідного батальйону - у проведенні антитерористичної операції (далі - АТО). 3 поданої заяви вбачалося, що встановлення вказаного фракту судом необхідне заявнику для подальшого отримання статусу учасника бойових дій.

Рішенням суду першої інстанції, залишеним без змін постановою суду апеляційної інстанції, вимоги заявника задоволено повністю - установлено фракт його участі у бойових діях під час проведення АТО у відповідний період.

Утім Велика Палата Верховного Суду визнала висновки суду першої й апеляційної інстанцій передчасними. Проаналізувавши релевантне законодавство, Велика Палата зауважила, що "встановлення факту участі особи в АТО є складовою процесу надання їй статусу учасника бойових дій, для якого визначений позасудовий порядок, який здійснюють спеціально уповноважені на це органи (комісії, міжвідомчі комісії). Первинним кроком зацікавленої особи задля отримання статусу учасника бойових дій $є$ звернення особи, яка претендує на надання статусу учасника бойових дій, до відповідної комісії, а за відмови в наданні такого статусу особа має право звертатися до суду для оскарження рішення комісії, зокрема щодо встановлення фракту участі в АТО чи інших подіях, які дають право на визнання його учасником бойових дій. Під час вирішення комісією питання про надання особі статусу учасника бойових дій підлягають дослідженню ті самі обставини, на які заявник покликався, обґрунтовуючи заяву про встановлення фракту його участі у бойових діях".

Таким чином, суд касаційної інстанції дійшов висновку, що на час звернення заявника до суду чинне законодавство передбачало позасудову процедуру підтвердження особою ї участі в бойових діях із метою отримання статусу учасника бойових дій. Визначено орган, який уповноважений приймати таке рішення, установлено перелік документів, необхідних для підтвердження участі особи в бойових діях. Перекладання на суд фуннкцій такого органу суперечило б вимогам закону, створило б умови для уникнення встановленої законодавством процедури отримання статусу учасника бойових дій і поставило б у нерівні умови осіб, які отримують такий статус із дотриманням цієї процедури. Враховуючи викладене, Велика Палата вирішила, що факт, про встановлення якого заявник просить суд, у межах окремого провадження встановленню не підлягає з огляду на існування позасудової процедури отримання статусу учасника бойових дій [5].

3 приводу четвертої ознаки допустимості встановлення юридичного фракту в межах окремого провадження, тобто у випадках, коли встановлення фракту не пов'язується з наступним вирішенням спору про право, звертаємо увагу на справу № 757/36438/18-ц, у якій заявниця просила суд встановити факт смерті свого чоловіка на тимчасово окупованій території України. Рішенням суду першої інстанції заяву задоволено повністю.

Проте особою, котра вважала, що рішенням місцевого суду вирішено питання про ії̈ права, відповідне рішення суду першої інстанції оскаржено в апеляційному порядку. На думку апелянта, справа має слухатись у порядку позовного провадження, позаяк установлення факту смерті чоловіка заявниці породжує для самого апелянта і його дружини юридичні наслідки, від яких залежить виконання, зміна або припинення майнових прав, оскільки, як вважав скаржник, установлення фракту смерті спрямоване на повторне стягнення 3 нього вже повернутих коштів за договором позики від 26.12.2013.

Утім апеляційний суд позицію скаржника не підтримав. Залишаючи апеляційну скаргу без задоволення, судом вказано, що покликання скаржника на те, що внаслідок ухвалення рішення 3 нього може бути стягнуто борг, який він повернув померлому, є лише недоведеним припущенням. Обставини повернення боргу не $є$ предметом дослідження у цій справі. Метою встановлення факту смерті у поданій заяві зазначено необхідність вступу у права як спадкоємниці. Причому, зважаючи на те, що сам апелянт спадкоємцем не є, то посилання на те, що заява підлягала залишенню без розгляду, з огляду на наявність спору про право, апеляційним судом відхилено [12].

Особливості суб'єктного складу учасників справи у провадженні щодо встановлення факту народження або смерті особи на тимчасово окупованій території України. Питання суб'єктного складу учасників у справах про встановлення факту народження або смерті особи на тимчасово окупованій території України регулюється, зокрема, ст. 317 ЦПК. Водночас названа правова норма чітко не визначає, які саме суб'єкти у цій категорії справ належать до "заявників" та "заінтересованих осіб". Утім ч. 1 ст. 317 ЦПК України передбачає, ким можуть бути подані заяви про встановлення фракту народження або ж смерті.

Зі змісту ст. 316 ЦПК України можна зробити висновок, що заявниками у справах окремого провадження стосовно встановлення фактів, котрі мають юридичне значення, зокрема щодо встановлення фракту смерті або народження на тимчасово окупованій території України, можуть бути виключно фрізичні особи. Можливості подання заяви юридичною особою у цьому випадку процесуальний закон не передбачає.

Згідно з абз. 1 ч.1 ст. 317 ЦПК України право на подання заяви про встановлення факту народження мають такі особи: батьки, родичі, їх представники й інші законні представники. Натомість відповідно до абз. 2 ч. 1 ст. 317 ЦПК України коло осіб, уповноважених на подання заяви про встановлення фракту смерті на тимчасово окупованій території, $є$ вужчим. До таких осіб належать родичі померлого та їх представники. Наведений перелік суб'єктів звернення породжує чимало запитань, зокрема, стосовно його виправданості, правильності розмежування за- 
конодавцем окремих категорій суб'єктів звернення, наприклад, "батьків" та "родичів", "представників" та "інших законних представників" тощо.

Почати аналіз суб'єктного складу учасників у справах про встановлення фактів народження або смерті на відповідній території України пропонується з категорії "батьків".

Батьки як суб'єкти звернення у справах про встановлення фактів народження або смерті особи на тимчасово окупованій території України. Визначення походження дитини здійснюють відповідно до вимог гл. 12 розд. III Сімейного кодексу України (далі СК України) [44]. Частиною 1 ст. 121 СК України дефріновано, що права й обов'язки матері, батька і дитини ґрунтуються на походженні дитини від них, засвідченому органом державної реєстрації актів цивільного стану. Отже, матір'ю та батьком дитини є особи, відомості про яких як про матір і батька внесено до актового запису про народження дитини. Утім батьками дитини у юридичному розумінні не обов'язково повинні бути саме біологічні батьки. Наприклад, згідно із ст. 123 СК України подружжя визнається батьками дитини, народженої дружиною після перенесення в її організм ембріона людини, зачатого їі чоловіком та іншою жінкою в результаті застосування допоміжних репродуктивних технологій.

Окрім цього, не варто забувати і про усиновлювачів. Частиною 4 ст. 232 СК України встановлено наслідки усиновлення для усиновлювача у вигляді покладення на останнього обов'язків щодо дитини, яку усиновлено, у такому ж обсязі, який мають батьки щодо дитини. Зазначимо, що ст. 229 СК України передбачено право усиновлювача бути записаним як батько чи мати дитини, котру усиновлено.

Підсумовуючи викладене, вважаємо, що до категорії "батьків" у розумінні абзацу 1 ч.1 ст.317 ЦПК України слід відносити: а) осіб, відомості про яких внесено до актового запису про народження дитини як про батьків незалежно від генетичного фактору; б) усиновлювачів безвідносно до того, чи змінено відомості, внесені до актового запису про народження усиновленого. При цьому, в другому випадку документом на підтвердження повноважень законного представника буде свідоцтво про усиновлення, видане на підставі відповідного судового рішення про усиновлення. Наступним етапом дослідження кола заявників у справах про встановлення фактів смерті та народження на тимчасово окупованій території є з'ясування переліку осіб, котрі охоплюються категорією "родичі".

Родичі як суб'єкти звернення у справах про встановлення фактів народження або смерті особи на тимчасово окупованій території України. Варто зауважити, що ЦПК не надає визначення цього поняття. Утім п. 1 ч. 1 ст. 36 ЦПК України використовує конструкцію "члени сім'ї та близькі родичі", що дозволяє стверджувати про розмежування законодавцем понять "близькі родичі" та "родичі".

Враховуючи вимоги ЦК та СК України, поняттям "родичі" охоплюють коло осіб, які пов'язані між собою певним ступенем споріднення [43]. Аналогічний підхід підтримано Львівським апеляційним судом у справі № 461/928/19. У ході апеляційного перегляду рішення суду першої інстанції колегія суддів судової палати 3 розгляду цивільних справ Львівського апеляційного суду зазначила, що "відповідно до вимог Цивільного кодексу України, Сімейного кодексу України поняттями "родичі", "родинні стосунки" охоплюється коло осіб, які пов'язані між собою певним ступенем споріднення. Такими особами можуть бути близькі родичі за по- ходженням, зокрема, батьки, діти, баба, дід, прабаба, прадід, внуки, правнуки, брат і сестра (повнорідні й неповнорідні), двоюрідні брати та сестри, тітка, дядько, племінниця, племінник. Усиновлений та усиновлювач прирівнюються до родичів за походженням" [26].

Із доктрини сімейного права випливає, що родичами можуть бути ті особи, котрі мають спорідненість. Причому така спорідненість є двох видів, а саме: за походженням і за шлюбом. Спорідненість за походженням $\epsilon$ кровною. Кровне споріднення зумовлене наявністю спільного предка. Окрім цього, кровну спорідненість мають особи, якщо одна походить від іншої. "Близькими родичами" називають осіб саме у разі спорідненості за походженням. Однак існує вузьке та широке розуміння цього поняття. У широкому розумінні під близькими розуміють родичів, спорідненість яких ґрунтується на походженні.

Вузьке розуміння вказаного поняття передбачає, що близьким $€$ родич, кровна спорідненість 3 яким обмежується однією горизонтальною та двома вертикальними ланками споріднення. Так, наприклад, для окремо взятої особи близькими родичами будуть їі рідні брати та/або сестри (горизонтальна ланка), а також її батьки, дід і баба, діти, внуки.

Що стосується споріднення за шлюбом, то воно існує між 4 групами осіб:

- між членами шлюбної пари;

- між дружиною і кровними родичами чоловіка;

- між чоловіком і кровними родичами дружини;

- між кровними родичами членів шлюбної пари.

Три останні різновиди споріднення за шлюбом побудовано на основі свояцтва. Отже, не можна погодитися із позицією, що члени сім'ї завжди є близькими родичами, але близькі родичі не завжди будуть членами однієї сім'ї [4]. Так, чоловік та жінка, котрі перебувають у шлюбі $€$ членами сім'ї та родичами, але саме близькими родичами вважатися не можуть. Враховуючи викладене, вважаємо, що родичами в розумінні ч. 1 cm. 317 ЦПК є не тільки близькі родичі, а й інші родичі за походженням, а також родичі на основі шлюбної спорідненості. Наступною групою осіб, котрі можуть звертатися до суду із заявою про встановлення факту народження на тимчасово окупованій території України $\epsilon$ представники батьків і родичів.

Представники як суб'єкти звернення у справах про встановлення фактів народження або смерті особи на тимчасово окупованій території України. Частиною 1 ст. 317 ЦПК персоніфіковано, що представники належать до "осіб, котрі вправі звернутися із заявою" в аналізованій нами категорії справ. Із цього приводу хочемо наголосити на такому.

Відповідно до ч. 1 ст. 60 ЦПК України представником у суді може бути адвокат або законний представник. 3 викладеного вбачається, що представництво $є$ законне та договірне. У зв'язку із цим вважаємо, що представники не можуть ототожнюватися із "заявниками" у справах, передбачених ч. $1 \mathrm{~cm}$. 317 ЦПК, оскільки відповідно до ч. $3 \mathrm{~cm} .42$ ЦПК учасником справи у справах окремого провадження $є$ заявник. Зазначимо, що представники $\epsilon$ учасниками судового процесу, але не $є$ учасниками справи. Вказане підтверджується тим, що законодавець названих учасників цивільно-процесуальних відносин розмежовує: положення учасників справи та представників, що регламентовано різними параграфами гл. 4 (учасники судового процесу).

Аналогічні висновки щодо договірного представництва викладено в постанові суду Донецького апеляційного суду у справі № 265/10710/18, в межах якої судовою колегією наголошено, що у адвоката відсутня 
як самостійна мета встановлення юридичного факту, так і власний інтерес до заявлених довірителем вимог, а тому "наявність у представника процесуальних прав, аналогічних довірителю, не переводить адвоката у статус заявника у вказаній справі і не підміняє його, як помилково висловлено в апеляційній скарзі" [8].

Резюмуючи дослідження суб'єктного складу осіб, котрі можуть подати до суду заяву з метою встановлення юридичного фракту на підставі ч. 1 ст. 317 ЦПК України, вважаємо за доцільне висловити зауваження стосовно виокремлення в абз. 1 ч. 1 ст. 317 ЦПК України одночасно "представників" та "інших законних представників", оскільки, як зауважувалося вище представництво вже автоматично включає в себе законне представництво.

Надалі пропонуємо повернутися до аналізу можливості звернення до суду іншими особами із заявою про встановлення факту народження або смерті на тимчасово окупованій території України, які прямо не перераховані у ч. 1 ст. 317 ЦПК України.

Допустимість подання заяв "іншими особами, для яких встановлення фракту народження(смерті) може мати юридичне значення" у справах про встановлення факту народження або смерті особи на тимчасово окупованій території України. Так, у справі № 265/6342/17 Верховний Суд зауважив, що "оскільки у померлої особи може не бути родичів, які можуть звернутися із заявою про встановлення відповідного фракту, з метою дотримання прав і свобод осіб, які проживають на тимчасово окупованій території, відповідна заява може бути подана членом сім'ї померлого, зокрема чоловіком або дружиною".

Якщо між заявником та померлим (померлою) родинні зв'язки відсутні, тоді перший із метою звернення до суду про встановлення фракту згідно зі ст. 317 ЦПК повинен підтвердити факт проживання однією сім'єю 3 померлим (померлою). Причому заявник має також довести фракт відсутності у померлого інших родичів, котрі могли б звернутися до суду для встановлення факту смерті на тимчасово окупованій території України [23].

Подібних висновків Харківський апеляційний суд дійшов у справі № 643/18607/19. Скасовуючи ухвалу місцевого суду, суд апеляційної інстанції наголосив на тому, що з урахуванням того, що у померлої особи може не бути родичів, які можуть звернутись із заявою про встановлення відповідного фракту, та враховуючи положення чинного законодавства, судам слід розглядати таку категорію справ у тому числі за заявами інших осіб, чиї права та законні інтереси підлягають захисту, оскільки право кожної особи на звернення до суду за захистом закріплено ст. 3 ЦПК України, частиною 1 якої передбачено, що кожна особа має право в порядку, установленому цим Кодексом, звернутися до суду за захистом своїх порушених, невизнаних або оспорюваних прав, свобод чи інтересів [30].

За наслідками проведеного дослідження можна зробити такі висновки. По-перше, перелік осіб, які вправі звернутися до суду з метою встановлення факту смерті або народження особи на тимчасово окупованій території України фрактично передбачає однакових суб'єктів звернення. По-друге, положення ч. 1 ст. 317 ЦПК не відповідає "якості закону", зважаючи на те, що загальне положення ст. 42 ЦПК учасниками справи при розгляді справ окремого провадження визначає заявника та заінтересовану особу та не містить жодних згадок про такого учасника справи як "особа, котра вправі подати заяву". По-третє, національні суди з метою забезпечення права на доступ до суду виправдано збільшили коло осіб, котрі вправі звернутися для встановлення факту смерті або народження на відповідній території України.

Отже, суб'єктами звернення на підставі ч. 1 ст. 317 ЦПК України є:

1) родичі особи, фракт народження або смерті якої встановлюється (зокрема й батьки та усиновлювачі);

2) інші особи, для яких встановлення факту смерті або народження іншої особи на тимчасово окупованій території України є підставою для виникнення, зміни чи припинення прав, якщо заявником доведено відсутність в особи, щодо якої встановлюється відповідний факт, інших родичів;

3) особи, які представляють заявників і діють у порядку договірного чи законного представництва.

Заінтересовані особи у провадженні щодо встановлення фактів народження або смерті особи на тимчасово окупованій території України. Що стосується заінтересованих осіб в аналізованій категорії справ, то звертаємо увагу на таке. Згідно з абз. 2 п. 3 розд. І Правил державної реєстрації актів цивільного стану в Україні за заявами громадян України, які проживають на тимчасово окупованій території України або переселилися з неї, державну реєстрацію актів цивільного стану, внесення змін до актових записів цивільного стану, їх поновлення й анулювання здійснюють відділи державної реєстрації актів цивільного стану за місцем звернення заявника [34]. Таким чином, як заінтересовану особу у провадженнях щодо встановлення фракту смерті або народження на тимчасово окупованій території України необхідно залучати територіальний орган, який відмовив у вчиненні відповідної реєстраційної дії.

Більше того, у справах про встановлення фракту народження дитини на тимчасово окупованій території України як заінтересовані особи мають залучатися батьки такої дитини або ж інший з них, якщо заява про встановлення вказаного факту подана першим, незалежно від того чи дружина з чоловіком проживають в офріційному або ж "цивільному" шлюбі $[28,32]$. Незалучення одного з батьків як заінтересованої особи $є$ порушенням права на визначення походження дитини від нього [18].

Проблеми правозастосовчої практики щодо доказування у справах про встановлення факту народження або смерті на тимчасово окупованій території України. До предмета доказування у справах про встановлення факту народження (смерті) на тимчасово окупованій території України входять обставини щодо часу і місця народження (смерті) - до того ж таке місце має бути "тимчасово окупованою територією"; неможливості встановлення бажаного фракту в позасудовому порядку; спричинення юридичним фактом юридичних наслідків для заявника; наявності родинних зв'язків між заявником та особою, щодо якої встановлюється фракт, а у випадках встановлення факту народження - з'ясування ідентифікаційних відомостей батьків дитини.

Так, у справі № 243/4047/19 за заявою про встановлення фракту смерті на тимчасово окупованій території України Донецький апеляційний суд указав, що предметом доказування у справах цієї категорії $€$ не сама подія смерті, а її чітко визначений час, який повинен породжувати для заявника правові наслідки. Для встановлення факту смерті особи необхідні обставини, що свідчать про цю подію, а також про те, що заінтересована особа позбавлена можливості зареєструвати факт смерті. Підставою для встановлення факту смерті $€$ підтверджені доказами обставини, які достовірно свідчать про смерть громадянина у певний час за певних 
обставин [7]. Аналогічний підхід щодо предмета доказування під час встановлення фракту смерті на відповідній території України підтримано у ряді інших судових справ [15, 17].

Що стосується встановлення фрактів народження в порядку ст. 317 ЦПК, то ситуація $€$ аналогічною. Так, аналіз судової практики дозволяє стверджувати, що предметом доказування у цій категорії справ $€$ чітко визначений час народження, який повинен породжувати для заявника правові наслідки $[41,39,42]$. Під час розгляду заяв про встановлення факту смерті на тимчасово окупованій території України суди обов'язково перевіряють наявність родинних зв'язків між заявником та особою, яка померла, з'ясовують неможливість встановлення відповідного факту в позасудовому порядку [11]. Також у разі звернення до суду із заявою про встановлення юридичного факту суди мають брати до уваги мету його встановлення, оскільки саме вона дає можливість зробити висновок, чи дійсно цей фракт $€$ юридичним і чи тягне він правові наслідки [31].

Правовим явищем, дотичним до предмета доказування, $є$ обов'язок доказування. Верховний Суд у справі № 707/1607/16-ц наголосив, що розгляд справ у порядку ст. 317 ЦПК повинен відбуватися за загальними правилами здійснення цивільного судочинства з урахуванням окремих винятків, їй притаманних; а отже, кожна сторона повинна довести ті обставини, які мають значення для справи і на які вона посилається як на підставу своїх вимог [20]. Таким чином, у справах про встановлення фракту народження або смерті на тимчасово окупованій території України обов'язок доказування покладається на заявника.

Що стосується ролі суду в межах аналізованої категорії справ, то, на наш погляд, він $€$ їх активним учасником, входячи до складу суб'єктів доказування, оскільки ст. 294 ЦПК України надає суду значні доказові повноваження, починаючи від формування предмета доказування, сприяння у встановленні обставин, забезпеченні й витребуванні доказів і закінчуючи їх дослідженням та оцінкою [3].

У ряді справ судами наголошувалось, що особливий характер справ, які розглядають у порядку окремого провадження, зумовлює певні особливості процесу доказування, зокрема, відсутність змагальності у справі, оскільки сторонами у процесі $є$ лише заявник і заінтересовані особи, активну позицію суду у процесі доказування, який за власним розсудом, з метою всебічного з'ясування обставин справи, може витребувати докази $[35,36,40]$.

Як правило, активність суду проявляється у витребуванні від органів реєстрації актів цивільного стану відомостей щодо наявності або ж відсутності актового запису стосовно смерті (народження) особи, відносно якої встановлюється відповідний факт $[49,46,50]$. Так, у справі № 756/3041/20 про встановлення фракту смерті на відповідній території України апеляційний суд, скасовуючи рішення суду першої інстанції про відмову у задоволенні заяви про встановлення факту смерті, звертав увагу на те, що, розглядаючи відповідні заяви, суди обов'язково повинні вжити заходів щодо витребування оригіналів документів, які підтверджують факт, з метою встановлення якого звернувся заявник [11].

Подібних висновків дійшов апеляційний суд також в іншій справі про встановлення фракту смерті на окупованій території України [24]. Скасовуючи рішення суду першої інстанції про відмову у задоволенні заяви 3 підстав неподання заявником окремих доказів, суд апеляційної інстанції вказав, що у разі ненадання заявником окремих доказів, як і у випадку долучення нена- лежно завірених копій певних доказів, суд управі самостійно витребувати необхідні докази. Утім судом першої інстанції цього враховано не було, а тому мала місце неповнота з'ясування обставин справи, що є підставою для скасування рішення.

Крім того, за розгляду справ у порядку ст. 317 ЦПК суди також призначають відповідні експертизи, наприклад, судово-медичні та судово-генетичні $[47,52,53]$. Зрештою, активність суду може обмежуватись фрормальною пропозицією подати заявнику додаткові докази для доведення факту, про встановлення якого він звернувся, що суд зазначає в ухвалі про відкриття провадження за заявою [51].

Окремо акцентуємо увагу на особливості оцінювання доказів у вказаній категорії справ, що зумовлена недопустимістю окремих засобів доказування, зважаючи на те, що будь-який акт (рішення, документ), виданий органами державної влади, місцевого самоврядування, підприємствами, установами, організаціями в умовах окупаційного режиму $\epsilon$ недійсним i не створює правових наслідків [33]. У зв'язку з викладеним судовою практикою вироблено так звані "намібійські винятки".

Під "намібійськими винятками" мають на увазі документи, видані окупаційною владою, які повинні братися судами до уваги, якщо їх нехтування веде за собою серйозні порушення чи обмеження прав громадян. Розгляд судами таких документів не означає автоматичного визнання окупаційної влади. Іншими словами - до уваги береться лише інформація документа без легітимізації останнього [45]. Щодо історії виникнення цього терміна, то вперше його сформулювали у висновку Міжнародного суду ООН 1971 р.: у документі "Юридичні наслідки для держав щодо триваючої присутності Південної Африки у Намібії" суд зазначив, що держави - члени ООН зобов'язані визнавати незаконність і недійсність триваючої присутності Південної Африки в Намібії, але ця недійсність не може бути застосовна до певних дій, наприклад, реєстрація народжень, смертей і шлюбів [1].

Аналіз судової практики дозволяє стверджувати, що нині суди по-різному застосовують "намібійський виняток" під час ухвалення рішень. Так, у справі № 490/5054/15-ц за позовом про стягнення страхового відшкодування, пені, інфляційних втрат і $3 \%$ річних Верховний Суд, скасовуючи постанову суду апеляційної інстанції, наголосив, що "намібійський виняток" може застосовуватися лише під час розгляду справ про встановлення факту народження або смерті особи на тимчасово окупованій території України, а не щодо стягнення грошових сум [21]. Аналогічний висновок сформульовано в іншій постанові Верховного Суду, у межах якої громадянин України звернувся до останньої (в особі Кабінету Міністрів України) з позовом про відшкодування майнової шкоди, заподіяної внаслідок проведення антитерористичної операції [19].

Утім у подібній справі - з тотожним складом учасників, аналогічними предметом та підставами позову Верховний Суд ухвалив діаметрально інше рішення та дійшов висновку про можливість застосування "намібійського винятку" до складеного акта обстеження квартири позивача на тимчасово окупованій території, яким, на переконання касаційного суду, підтверджено обставину знищення багатоквартирного будинку, в якому мешкав позивач у зв'язку з потраплянням снаряду [22].

Отже, з викладеного неважко побачити, що Верховний Суд, завданням якого є забезпечення єдності судової практики, і сам по-різному застосовує "намібійський виняток", надаючи оцінку доказам у справі. 
У справі № 707/1607/16-ц про встановлення фракту смерті на тимчасово окупованій території України Верховний Суд зазначав, що досліджуючи виключно докази, надані органами, утвореними на тимчасово окупованій території, суд позбавлений можливості належним чином установити факт смерті на непідконтрольній Україні території [20].

Схожими мотивами керувався також Запорізький апеляційний суд у справі № 233/6471/18, в якій заявник подав заяву про встановлення факту смерті свого батька на тимчасового окупованій території України [10]. Заявником на доведення відповідного факту подано лише ксерокопію лікарського свідоцтва, виданого на території так званої "ДНР". Апеляційний суд підтримав правильність висновку суду першої інстанції про недоведеність заявником факту смерті батька, оскільки першим не мотивовано, з яких причин у нього залишився паспорт загиблого, лікарське свідоцтво, видане у так званій "ДНР", та дозвіл на поховання, завірені ним самим, без надання жодних оригіналів цих документів. Також не надано жодних інших доказів на підтвердження фракту смерті, а самі по собі лікарські довідки, видані на окупованій території не можуть бути визнані достовірними без узгодження 3 іншими доказами, які підтверджували б факт смерті.

Київський апеляційний суд зауважив, що встановлення фракту народження або смерті особи має значення для реалізації майнових та особистих немайнових прав заявника, рішення суду в такій категорії справ повинне ґрунтуватися на дотриманні вимог процесуального закону щодо повного та всебічного з'ясування обставин справи на підставі всіх поданих особами, які беруть участь у справі, доказів у сукупності, у тому числі 3 урахуванням документів, виданих органами й установами самопроголошених утворень, розташованими на окупованій території України [13]. Причому чинне законодавство не містить положень, які б визначали, якими документами має бути посвідчено фракт смерті особи на тимчасово окупованій території [15].

У справах про встановлення фактів народження на відповідній території України суди під час ухвалення рішень застосовують "намібійський виняток" за наявності свідоцтва про народження або його копії, виданого за зразками так званих "ЛНР" чи "ДНР" та наявності медичного свідоцтва про народження дитини на непідконтрольній території [9, 25]. Усвідомлюючи те, що можливість збору доказів народження особи на окупованій території $\epsilon$ обмеженою, у той час як встановлення цього фракту має істотне значення, ми вважаємо приклади вказаного правозастосування неприпустимими. На жаль, обґрунтовані судові рішення у справах про встановлення факту народження в порядку ст. 317 ЦПК є рідкістю.

На наш погляд, таким фактом $є$ постанова Київського апеляційного суду у справі № 757/26862/19-ц [16]. У вказаній справі заявник звернувся до місцевого суду із заявою про встановлення фракту народження дитини на території АР Крим. До поданої заяви долучено виключно копію свідоцтва про народження дитини, зі змісту якого вбачалось, що воно видане Нижньогірським районним відділом записів актів цивільного стану Департаменту записів актів цивільного стану Міністерства юстиції Республіки Крим Російської Федерації.

Апеляційний суд вказав, що при наданні оцінки свідоцтву про народження дитини, як доказу, береться до уваги, що хоча такий документ не $є$ юридично дійсним, але він може підтверджувати, що певна установа, яка не діє відповідно до українського законодавства, але de facto існує на окупованій території, за- реєструвала факт народження певної особи. Окрім цього, колегія суддів звернула увагу, що сам по собі фракт перебування заявника на тимчасово окупованій території Автономної Республіки Крим і встановлення законом особливого порядку розгляду заяв про встановлення факту народження особи на тимчасово окупованій території України, визначеній Верховною Радою України, не $є$ безумовною підставою для встановлення такого факту та не звільняє заявника від надання суду належних доказів на підтвердження своїх вимог. Зважаючи на викладене, суд апеляційної інстанції, залишаючи рішення суду першої інстанції без змін, дійшов правильного висновку про відсутність підстав для задоволення заяви.

Таким чином, здійснюючи оцінювання доказів у справах про встановлення фракту смерті або народження відповідно до ст. 317 ЦПК, суди повинні застосовувати "намібійський виняток" у випадку підтвердження відповідного фракту також іншими доказами, окрім отриманих на тимчасово окупованій території. 3 урахуванням того, що чинне законодавство не визначає, якими саме доказами повинні підтверджуватися фракт смерті або народження, то прикладами таких можуть бути договори про організацію поховань, акти про надання ритуальних послуг, фьотографрії з місия поховань, показання свідків, акти медичних консультаційних комісій, висновки судовомедичних, генетичних та інших експертиз тощо.

ВИСНОВКИ. За наслідками проведеного дослідження можна дійти таких висновків.

1. У порядку окремого провадження розглядають справи про встановлення фактів у таких випадках: ці факти породжують юридичні наслідки, тобто від них залежить виникнення, зміна або припинення особистих чи майнових прав громадян; чинним законодавством не передбачено іншого порядку їх установлення; заявник не має іншої можливості одержати або відновити загублений чи знищений документ, який посвідчує факт, що має юридичне значення; установлення факту не пов'язується з наступним вирішенням спору про право, справи щодо встановлення фрактів народження або смерті на тимчасово окупованій території відповідають природі категорій справ, котрі можуть розглядатися в межах окремого провадження, а тому й самі повинні слухатись у названому виді провадження.

Суб'єктами звернення для встановлення відповідного фракту на тимчасово окупованій території України є: а) родичі особи, факт народження або смерті якої встановлюється (у тому числі й батьки й усиновлювачі); б) інші особи, для яких встановлення факту смерті або народження іншої особи на тимчасово окупованій території України є підставою для виникнення, зміни чи припинення прав, якщо заявником доведено відсутність в особи, щодо якої встановлюється відповідний факт, інших родичів; в) особи, які представляють заявників і діють у порядку договірного чи законного представництва.

2. До предмета доказування у справах про встановлення факту народження (смерті) на тимчасово окупованій території України входять обставини: 1) часу і місця народження (смерті) - до того ж таке місце повинно бути "тимчасово окупованою територією"; 2) неможливості встановлення бажаного фракту в позасудовому порядку; 3) спричинення юридичним фрактом юридичних наслідків для заявника; 4) наявності родинних зв'язків між заявником та особою, щодо якої встановлюється фракт, а у випадках встановлення факту народження - з'ясування ідентифрікаційних відомостей батьків дитини. 
3. Обов'язок доказування у справах аналізованої категорії покладають на заявника. Поряд із цим, національні суди повинні вживати заходів щодо всебічного, повного й об'єктивного з'ясування обставин справи, зокрема затребувати необхідні докази, призначити відповідні експертизи.

4. Застосування "намібійського винятку" є правомірним виключно у випадках підтвердження обставин настання фокту народження (смерті) іншими належними, допустимими та достовірними доказами, отриманими не на території, де функціонують органи окупаційної влади. Причому належними й допустимими письмовими доказами у цій категорії справ $€$ договори про організацію поховань, акти про надання ритуальних послуг, фотографії з місця поховань, показання свідків, акти медичних консультаційних комісій, висновки судово-медичних, генетичних та інших експертиз тощо.

\section{Список використаних джерел}

1. Legal consequences for states of the continued presence of south africa in namibia (south-west africa) notwithstanding security council resolution 276 (1970). - 1971 [Електронний ресурс] - Режим доступу до ресурcy: https://www.icj-cij.org/files/case-related/53/5597.pdf.

2. Васильєв С. В. Порівняльний цивільний процес / С. В. Васильєв // Правова єдність. - 2015 [Електронний ресурс] - Режим доступу до pecypcy: http://dspace.nlu.edu.ua/bitstream/123456789/9642/1/Vasilyev_ PCP 2015.pdf.

3. Дрогозюк К. Б. Предмет та суб'єкти доказування у цивільному процесі України та Франції : автореф. дис. ... канд. юрид. наук : спец. 12.00.03 "Цивільне право і цивільний процес; сімейне право; міжнародне приватне право" / К. Б. Дрогозюк. - О. , 2018. - 22 с.

4. Карчевський К. А. Родинний критерій поняття "афрілійована особа" (в контексті правового режиму правочинів із заінтересованістю) / К. А. Карчевський // Вісник ХНУВС. - 2014 [Електронний ресурс] - Режим доступу до ресурсу: file:///C:/Users/user/Downloads/40200.pdf.

5. Постанова ВП ВС від 03 липня 2019 року у справі № 233/2929/17 [Електронний ресурс] - Режим доступу до ресурсу: http://www.reyestr.court.gov.ua/Review/82998173.

6. Постанова ВП ВС від 23 січня 2019 року у справі № 536/1039/17 [Електронний ресурс] - Режим доступу до ресурсу: http://www.reyestr.court.gov.ua/Review/79516806.

7. Постанова Донецького апеляційного суду від 06.08.2019 у справі № 243/4047/19 [Електронний ресурс] - Режим доступу до ресурcy: http://reyestr.court.gov.ua/Review/83557953.

8. Постанова Донецького апеляційного суду від 20.02.2019 у справі № 265/10710/18 [Електронний ресурс] - Режим доступу до ресурсу: http://www.reyestr.court.gov.ua/Review/80048482.

9. Постанова Донецького апеляційного суду від 31.03.2020 у справі № 234/19229/19 [Електронний ресурс] - Режим доступу до реcypcy: http://reyestr.court.gov.ua/Review/88539634.

10. Постанова Запорізького апеляційного суду від 11.06.2019 у справі № 233/6471/18 [Електронний ресурс] - Режим доступу до ресурcy: http://reyestr.court.gov.ua/Review/82439322.

11. Постанова Київського апеляційного суду від 01.07.2020 у справі № 756/3041/20 [Електронний ресурс] - Режим доступу до ресурcy: http://reyestr.court.gov.ua/Review/90143292.

12. Постанова Київського апеляційного суду від 02.09 .2020 у справі № 757/36438/18-ц [Електронний ресурс] - Режим доступу до pecypcy: http://reyestr.court.gov.ua/Review/91366099.

13. Постанова Київського апеляційного суду від 03.06.2020 у справі № 761/3106/20 [Електронний ресурс] - Режим доступу до ресурcy: http://reyestr.court.gov.ua/Review/89698903.

14. Постанова Київського апеляційного суду від 06.03.2019 у справі № 757/20810/18-ц [Електронний ресурс] - Режим доступу до pecypcy: http://reyestr.court.gov.ua/Review/80304067.

15. Постанова Київського апеляційного суду від 18.12 .2019 у справі № 761/4311/19 [Електронний ресурс] - Режим доступу до ресурcy: http://reyestr.court.gov.ua/Review/86497422.

16. Постанова Київського апеляційного суду від 21.01.2020 у справі № 757/26862/19-ц [Електронний ресурс] - Режим доступу до pecypcy: http://reyestr.court.gov.ua/Review/87242378.

17. Постанова Київського апеляційного суду від 25.09.2019 у справі № 759/10122/19 [Електронний ресурс] - Режим доступу до реcypcy: http://reyestr.court.gov.ua/Review/84565815.

18. Постанова Кропивницького апеляційного суду від 20.02 .2020 у справі № 396/1861/19 [Електронний ресурс] - Режим доступу до ресурcy: http://www.reyestr.court.gov.ua/Review/87946666.

19. Постанова КЦС у складі від 01.07.2020 у справі № 185/9816/16-ц [Електронний ресурс] - Режим доступу до ресурсу: http://reyestr.court.gov.ua/Review/90349589.

20. Постанова КЦС у складі ВС від 20.12.2018 у справі № 707/1607/16-ц [Електронний ресурс] - Режим доступу до ресурсу: http://reyestr.court.gov.ua/Review/78978236.
21. Постанова КЦС у складі ВС від 24.10.2018 у справі № 490/5054/15-ц [Електронний ресурс] - Режим доступу до ресурсу: http://reyestr.court.gov.ua/Review/77473491.

22. Постанова КЦС у складі ВС від 25.03.2020 у справі № 310/1739/17 [Електронний ресурс] - Режим доступу до ресурсу: http://reyestr.court.gov.ua/Review/88575080.

23. Постанова КЦС у складі ВС від 25.04.2019 у справі № 265/6342/17 [Електронний ресурс] - Режим доступу до ресурсу: http://www.reyestr.court.gov.ua/Review/82156791.

24. Постанова Луганського апеляційного суду від 07.05.2019 у справі № 414/672/19 [Електронний ресурс] - Режим доступу до ресурсу: http://reyestr.court.gov.ua/Review/81610117.

25. Постанова Луганського апеляційного суду від 15.10.2019 у справі №428/6207/19 [Електронний ресурс] - Режим доступу до ресурcy: http://reyestr.court.gov.ua/Review/84964098.

26. Постанова Львівського апеляційного суду від 17.03 .2020 у справі № 461/928/19 [Електронний ресурс] - Режим доступу до ресурсу: http://www.reyestr.court.gov.ua/Review/88321826.

27. Постанова Миколаївського апеляційного суду від 15 квітня 2019 року у справі № 473/1039/19 [Електронний ресурс] - Режим доступу до ресурсу: https://reyestr.court.gov.ua/Review/81201261.

28. Постанова Одеського апеляційного суду від 06.02.2020 у справі № 522/5189/19№ [Електронний ресурс] - Режим доступу до pecypcy: http://www.reyestr.court.gov.ua/Review/87495964.

29. Постанова Пленуму Верховного Суду України "Про судову практику в справах про встановлення фактів, що мають юридичне значення" № 5 від 31.03.1995 [Електронний ресурс] - Режим доступу до pecypcy: https://zakon.rada.gov.ua/laws/show/v0005700-95\#Text.

30. Постанова Харківського апеляційного суду від 08.01.2020 у справі № 643/18607/19 [Електронний ресурс] - Режим доступу до реcypcy: http://reyestr.court.gov.ua/Review/86790701.

31. Постанова Харківського апеляційного суду від 16.09.2019 у справі № 645/1211/19 [Електронний ресурс] - Режим доступу до ресурcy: http://reyestr.court.gov.ua/Review/84342680.

32. Постанова Херсонського апеляційного суду від 18.07.2019 у справі № 766/8260/19 [Електронний ресурс] - Режим доступу до ресурcy: http://www.reyestr.court.gov.ua/Review/83131931.

33. Про забезпечення прав і свобод громадян та правовий режим на тимчасово окупованій території України: Закон України від 15 квітня 2014 р. [Електронний ресурс] - Режим доступу до ресурсу: https://zakon.rada.gov.ua/laws/show/1207-18\#Text.

34. Про затвердження правил державної реєстрації актів цивільного стану в Україні: наказ Міністерства юстиції України № 52/5 від 18 жовтня 2000 р. [Електронний ресурс] - Режим доступу до ресурсу: https://zakon.rada.gov.ua/laws/show/z0719-00\#Text.

35. Рішення Краматорського міського суду Донецької області від 01.09.2020 у справі № 234/12199/20 [Електронний ресурс] - Режим доступу до ресурсу: http://reyestr.court.gov.ua/Review/91921144.

36. Рішення Краматорського міського суду Донецької області від 24.10.2019 у справі № 234/18156/19 [Електронний ресурс] - Режим доступу до ресурсу: http://reyestr.court.gov.ua/Review/85597789.

37. Рішення Малинівського районного суду Житомирської області від 07 червня 2019 року у справі № 283/1265/19 [Електронний ресурс] Режим доступу до ресурсу: https://reyestr.court.gov.ua/Review/82259504.

38. Рішення Новопсковського районного суду Луганської області від 23 вересня 2020 року у справі № 942/876/20 [Електронний ресурс] Режим доступу до ресурсу: https://reyestr.court.gov.ua/Review/91898150.

39. Рішення Оболонського районного суду міста Києва від 10.04.2019 у справі № 756/4979/19 [Електронний ресурс] - Режим доступу до ресурсу: http://reyestr.court.gov.ua/Review/81259980.

40. Рішення Селидівського міського суду Донецької області від 23.04.2019 у справі № 242/2317/19 [Електронний ресурс] - Режим доступу до ресурсу: http://reyestr.court.gov.ua/Review/81381139.

41. Рішення Слов'янського міськрайонного суду Донецької області від 05.07.2019 у справі №243/7164/19 [Електронний ресурс] - Режим доступу до ресурсу: http://reyestr.court.gov.ua/Review/82834398.

42. Рішення Слов'янського міськрайонного суду Донецької області від 13.03.2019 у справі № 243/2383/19 [Електронний ресурс] - Режим доступу до ресурсу: http://reyestr.court.gov.ua/Review/80430608.

43. Роз'яснення Національного банку України "Щодо практичного застосування окремих вимог нормативно-правового акта Національного банку України" від 03 квітня 2008 року [Електронний ресурс] - Режим доступу до ресурсу: https://zakon.rada.gov.ua/laws/show/v4193500-08\#Text.

44. Сімейний кодекс України від 10 січня 2002 р. [Електронний ресурс] - Режим доступу до ресурсу: https://zakon.rada.gov.ua/laws/show/ 2947-14\#n595.

45. Увага: визнанням окремих довідок з ОРдЛО владу окупантів ніхто не легалізує.- 2019. - [Електронний ресурс] - Режим доступу до pecypcy: https://www.ukrinform.ua/rubric-society/2806155-uvaga-viznannamokremim-dovidok-z-ordlo-vladu-okupantiv-nihto-ne-legalizue.html.

46. Ухвала Добропільського міськрайонного суду Донецької області від 01.07.2019 у справі № 227/2696/19 [Електронний ресурс] Режим доступу до ресурсу: http://reyestr.court.gov.ua/Review/82725650.

47. Ухвала Жовтневого районного суду міста Маріуполя від 11.06.2019 у справі № 263/7330/19 [Електронний ресурс] - Режим доступу до ресурсу: http://reyestr.court.gov.ua/Review/82430176.

48. Ухвала Київського районного суду міста Полтави від 25.10.2019 у справі № 552/5900/19 [Електронний ресурс] - Режим доступу до ресурсу: http://www.reyestr.court.gov.ua/Review/85246253. 
49. Ухвала Слов'янського міськрайонного суду Донецької області від 07.09.2020 у справі № 243/7678/20 [Електронний ресурс] - Режим доступу до ресурсу: http://reyestr.court.gov.ua/Review/91373343.

50. Ухвала Слов'янського міськрайонного суду Донецької області від 28.07.2020 у справі № 243/6340/20 [Електронний ресурс] - Режим доступу до ресурсу: http://reyestr.court.gov.ua/Review/90622388.

51. Ухвала Слов'янського міськрайонного суду Донецької області від 28.09.2020 у справі № 243/8450/20 [Електронний ресурс] - Режим доступу до ресурсу: http://reyestr.court.gov.ua/Review/91860096.

52. Ухвала Суворовського районного суду міста Одеси від 05.12.2019 у справі № 523/11553/19 [Електронний ресурс] - Режим доступу до ресурсу: http://reyestr.court.gov.ua/Review/86205376.

53. Ухвала Суворовського районного суду міста Одеси від 13.02.2020 у справі № 523/18599/19 [Електронний ресурс] - Режим доступу до ресурсу: http://reyestr.court.gov.ua/Review/87583139.

\section{References}

1. Legal consequences for states of the continued presence of south africa in namibia (south-west africa) notwithstanding security council resolution 276 (1970) [Електронний ресурс]. - 1971. - Режим доступу до реcypcy: https://www.icj-cij.org/files/case-related/53/5597.pdf (in English)

2. Vasyl'jev S. V. Porivnjal'nyj cyvil'nyj proces [Comparative civil proceedings] Pravova jednist'. 2015. URL: http://dspace.nlu.edu.ua/bitstream/ 123456789/9642/1/Nasilyev_PCP_2015.pdf (in Ukrainian)

3. Drogozjuk K. B. Predmet ta sub'jekty dokazuvannja u cyvil'nomu procesi Ukrai'ny ta Francii' [Subject and subjects of proof in civil proceedings of Ukraine and France]: avtoref. dys. na zdobuttja nauk. stupenja kand. jur. nauk : spec. 12.00 .03 "cyvil'ne pravo i cyvil'nyj proces; simejne pravo; mizhnarodne pryvatne pravo". Odesa, 2018. 22 s. (in Ukrainian)

4. Karchevs'kyj K. A. Rodynnyj kryterij ponjattja "afilijovana osoba" (v konteksti pravovogo rezhymu pravochyniv Iz zainteresovanistju) [Family criterion of the concept of "affiliated person" (in the context of the legal regime of transactions with interest)]. Visnyk HNUVS. 2014. URL: file:///C:/Users/user/Downloads/40200.pdf. (in Ukrainian)

5. Postanova VP VS vid 03 lypnja 2019 roku u spravi №233/2929/17. URL: http://www.reyestr.court.gov.ua/Review/82998173 (in Ukrainian)

6. Postanova VP VS vid 23 sichnja 2019 roku u spravi №536/1039/17. URL: http://www.reyestr.court.gov.ua/Review/79516806. (in Ukrainian)

7. Postanova Donec'kogo apeljacijnogo sudu vid 06.08.2019 u spravi №243/4047/19. URL: http://reyestr.court.gov.ua/Review/83557953. (in Ukrainian)

8. Postanova Donec'kogo apeljacijnogo sudu vid 20.02.2019 u spravi №265/10710/18. URL http://www.reyestr.court.gov.ua/Review/80048482. (in Ukrainian)

9. Postanova Donec'kogo apeljacijnogo sudu vid 31.03 .2020 u spravi №234/19229/1. URL: http://reyestr.court.gov.ua/Review/88539634. (in Ukrainian)

10. Postanova Zaporiz'kogo apeljacijnogo sudu vid 11.06 .2019 u spravi №233/6471/18. URL: http://reyestr.court.gov.ua/Review/82439322. (in Ukrainian)

11. Postanova Kyi'vs'kogo apeljacijnogo sudu vid 01.07.2020 u spravi №756/3041/20. URL: http://reyestr.court.gov.ua/Review/90143292. (in Ukrainian)

12. Postanova Kyi'vs'kogo apeljacijnogo sudu vid 02.09 .2020 u spravi №757/36438/18-c. URL: http://reyestr.court.gov.ua/Review/91366099. (in Ukrainian)

13. Postanova Kyi'vs'kogo apeljacijnogo sudu vid 03.06.2020 u spravi №761/3106/2. URL: http://reyestr.court.gov.ua/Review/89698903. (in Ukrainian)

14. Postanova Kyi'vs'kogo apeljacijnogo sudu vid 06.03.2019 u sprav №757/20810/18-c. URL http://reyestr.court.gov.ua/Review/80304067. (in Ukrainian)

15. Postanova Kyi'vs'kogo apeljacijnogo sudu vid 18.12.2019 u spravi №761/4311/1. URL: http://reyestr.court.gov.ua/Review/86497422. (in Ukrainian)

16. Postanova Kyi'vs'kogo apeljacijnogo sudu vid 21.01.2020 u spravi №757/26862/19-. URL: http://reyestr.court.gov.ua/Review/87242378. (in Ukrainian)

17. Postanova Kyi'vs'kogo apeljacijnogo sudu vid 25.09.2019 u spravi №759/10122/19. URL: http://reyestr.court.gov.ua/Review/84565815. (in Ukrainian)

18. Postanova Kropyvnyc'kogo apeljacijnogo sudu vid 20.02 .2020 u spravi №396/1861/19. URL http://www.reyestr.court.gov.ua/Review/ 87946666. (in Ukrainian)

19. Postanova KCS u skladi vid 01.07.2020 u spravi №185/9816/16-C. URL http://reyestr.court.gov.ua/Review/90349589. (in Ukrainian)

20. Postanova KCS u skladi VS vid 20.12.2018 u spravi №707/1607/16-c. URL: http://reyestr.court.gov.ua/Review/78978236. (in Ukrainian)

21. Postanova KCS u skladi VS vid 24.10.2018 u spravi №490/5054/15-c. URL: http://reyestr.court.gov.ua/Review/77473491. (in Ukrainian).

22. Postanova KCS u skladi VS vid 25.03.2020 u spravi №310/1739/17. URL: http://reyestr.court.gov.ua/Review/88575080. (in Ukrainian).

23. Postanova KCS u skladi VS vid 25.04.2019 u spravi №265/6342/1 URL: http://www.reyestr.court.gov.ua/Review/82156791. (in Ukrainian)

24. Postanova Lugans'kogo apeljacijnogo sudu vid 07.05.2019 u spravi №414/672/1. URL: http://reyestr.court.gov.ua/Review/81610117. (in Ukrainian)
25. Postanova Lugans'kogo apeljacijnogo sudu vid 15.10 .2019 u spravi №428/6207. URL: http://reyestr.court.gov.ua/Review/84964098. (in Ukrainian)

26. Postanova L'vivs'kogo apeljacijnogo sudu vid 17.03 .2020 u spravi №461/928/1. URL: http://www.reyestr.court.gov.ua/Review/88321826. (in Ukrainian)

27. Postanova Mykolai'vs'kogo apeljacijnogo sudu vid 15 kvitnja 2019 roku u spravi №473/1039/19. URL: https://reyestr.court.gov.ua/Review/ 81201261. (in Ukrainian)

28. Postanova Odes'kogo apeljacijnogo sudu vid 06.02.2020 u spravi №522/5189/19№. URL: http://www.reyestr.court.gov.ua/Review/87495964. (in Ukrainian)

29. Postanova Plenumu Verhovnogo Sudu Ukrai'ny "Pro sudovu praktyku v spravah pro vstanovlennja faktiv, shho majut' jurydychne znachennja" №5 vid 31.03.1995. URL: https://zakon.rada.gov.ua/laws/show/v000570095\#Text. (in Ukrainian)

30. Postanova Harkivs'kogo apeljacijnogo sudu vid 08.01.2020 u spravi №643/18607/19. URL: http://reyestr.court.gov.ua/Review/86790701. (in Ukrainian)

31. Postanova Harkivs'kogo apeljacijnogo sudu vid 16.09.2019 u spravi №645/1211/19. URL: http://reyestr.court.gov.ua/Review/84342680. (in Ukrainian)

32. Postanova Hersons'kogo apeljacijnogo sudu vid 18.07.2019 u spravi №766/8260/19. URL: http://www.reyestr.court.gov.ua/Review/ 83131931. (in Ukrainian)

33. Pro zabezpechennja prav i svobod gromadjan ta pravovyj rezhym na tymchasovo okupovanij terytorii' Ukrai'ny: Zakon Ukrai'ny vid 15 kvitnja 2014 r. URL: https://zakon.rada.gov.ua/laws/show/1207-18\#Text. (in Ukrainian)

34. Pro zatverdzhennja pravyl derzhavnoi' rejestracii' aktiv cyvil'nogo stanu v Ukrai'ni: nakaz Ministerstva justycii' Ukrai'ny №52/5 vid 18 zhovtnja 2000r. URL: https://zakon.rada.gov.ua/laws/show/z0719-00\#Text. (in Ukrainian)

35. Rishennja Kramators'kogo mis'kogo sudu Donec'koi' oblasti vid 01.09.2020 u spravi №234/12199/20. URL: http://reyestr.court.gov.ua/ Review/91921144. (in Ukrainian)

36. Rishennja Kramators'kogo mis'kogo sudu Donec'koi' oblasti vid 24.10.2019 u spravi №234/18156/19. URL: http://reyestr.court.gov.ua/ Review/85597789. (in Ukrainian)

37. Rishennja Malynivs'kogo rajonnogo sudu Zhytomyrs'koi' oblasti vid 07 chervnja 2019 roku u spravi №283/1265/19. URL: https://reyestr.court.gov.ua/ Review/82259504. (in Ukrainian)

38. Rishennja Novopskovs'kogo rajonnogo sudu Lugans'koi' oblasti vid 23 veresnja 2020 roku u spravi №942/876/20. URL: https://reyestr.court.gov.ua/ Review/91898150. (in Ukrainian)

39. Rishennja Obolons'kogo rajonnogo sudu mista Kyjeva vid 10.04.2019 u spravi №756/4979/19. URL: http://reyestr.court.gov.ua/ Review/81259980. (in Ukrainian)

40. Rishennja Selydivs'kogo mis'kogo sudu Donec'koi' oblasti vid 23.04.2019 u spravi №242/2317/19. URL: http://reyestr.court.gov.ua/ Review/81381139. (in Ukrainian)

41. Rishennja Slov'jans'kogo mis'krajonnogo sudu Donec'koi' oblasti vid 05.07.2019 u spravi №243/7164/19. URL: http://reyestr.court.gov.ua/ Review/82834398. (in Ukrainian)

42. Rishennja Slov'jans'kogo mis'krajonnogo sudu Donec'koi' oblasti vid 13.03.2019 u spravi №243/2383/19. URL: http://reyestr.court.gov.ua/ Review/80430608. (in Ukrainian).

43. Roz'jasnennja Nacional'nogo banku Ukrai'ny "Shhodo praktychnogo zastosuvannja okremyh vymog normatyvno-pravovogo akta Nacional'nogo banku Ukrai'ny" vid 03 kvitnja 2008 roku. URL: https://zakon.rada.gov.ua/laws/show/v4193500-08\#Text. (in Ukrainian).

44. Simejnyj kodeks Ukrai'ny vid 10 sichnja 2002 r. URL: https://zakon.rada.gov.ua/laws/show/2947-14\#n595. (in Ukrainian)

45. Uvaga: vyznannjam okremym dovidok z ORDLO vladu okupantiv nihto ne legalizuje. URL: https://www.ukrinform.ua/rubric-society/2806155uvaga-viznannam-okremim-dovidok-z-ordlo-vladu-okupantiv-nihto-ne-

legalizue.html. (in Ukrainian)

46. Uhvala Dobropil's'kogo mis'krajonnogo sudu Donec'koi' oblasti vid 01.07.2019 u spravi №227/2696/19. URL: http://reyestr.court.gov.ua/ Review/82725650. (in Ukrainian)

47. Uhvala Zhovtnevogo rajonnogo sudu mista Mariupolja vid 11.06.2019 u spravi №263/7330/19. URL: http://reyestr.court.gov.ua/ Review/82430176. (in Ukrainian)

48. Uhvala Kyi'vs'kogo rajonnogo sudu mista Poltavy vid 25.10 .2019 u spravi №552/5900/19. URL: http://www.reyestr.court.gov.ua/Review/ 85246253. (in Ukrainian)

49. Uhvala Slov'jans'kogo mis'krajonnogo sudu Donec'koi' oblasti vid 07.09.2020 u spravi №243/7678/20. URL: http://reyestr.court.gov.ua/ Review/91373343. (in Ukrainian)

50. Uhvala Slov'jans'kogo mis'krajonnogo sudu Donec'koi' oblasti vid 28.07.2020 u spravi №243/6340/20. URL: http://reyestr.court.gov.ua/ Review/90622388. (in Ukrainian)

51. Uhvala Slov'jans'kogo mis'krajonnogo sudu Donec'koi' oblasti vid 28.09.2020 u spravi №243/8450/20. URL: http://reyestr.court.gov.ua/ Review/91860096. (in Ukrainian)

52. Uhvala Suvorovs'kogo rajonnogo sudu mista Odesy vid 05.12.2019 u spravi №523/11553/19. URL: http://reyestr.court.gov.ua/ Review/86205376. (in Ukrainian)

53. Uhvala Suvorovs'kogo rajonnogo sudu mista Odesy vid 13.02.2020 u spravi №523/18599/19. URL: http://reyestr.court.gov.ua/ Review/87583139. (in Ukrainian) 
O. Ugrunovska, PhD (Law), Associate Prof.,

M. Piniashko, Master Student

Ivan Franko National University of Lviv, Lviv, Ukraine

\section{PROCEEDINGS IN CASES REGARDING THE ESTABLISHMENT OF BIRTH OR DEATH OF A PERSON ON THE TEMPORARILY OCCUPIED TERRITORY OF UKRAINE}

The article examines the functioning of the judicial procedure for establishing the facts of birth and death on the temporarily occupied territory of Ukraine in terms of its regulation and effectiveness. The authors analyze the procedural nature of the separate proceeding according to national legislation of Ukraine in comparison with legal framework of several foreign states. As a result, it has been stated that the establishment of the above-mentioned legal facts is not the only Ukrainian know-how.

Specific attention has been paid to the issues of juridical technique regarding the determination of participants that can submit an application in order to set a fact of birth or death of a person. In particular, it has been found that Ukrainian legislator does not circumscribe such categories as "persons who can hand in an application" and "applicants". It has been delineated that lodging an application by the applicant's attorney does not substitute the presence of the independent legal interest, which is necessary to become applicant.

In addition, the article explores the process of proving. It has been concluded that the burden of proof rests on the applicant. However, the court is obliged to be an active participant of the proving in order to establish the circumstances of the case, namely: to request evidence, order to carry out expertise etc. The subject-matter of the cases concerning the establishment of facts of birth or death of a person on the temporarily occupied territory of Ukraine comprises, inter alia, the circumstances regarding time and place of birth (death), familial relationships between the applicant and the person who was born (died). Finally, the article examines the enforcement of the "Namibian exception" in the context of the evaluation of the evidence.

Key words: separate proceedings, court decision, occupied territory, "Namibian exception".

Bulletin of Taras Shevchenko National University of Kyiv. Legal Studies, 2020; 3 (114): 59-63

УДК: 349.2

DOI: https:doi.org/10.17721/1728-2195/2020/5.115-12
ISSN 1728-2195

(C) Taras Shevchenko National University of Kyiv, Publishing center "Kyiv University", 2020

А. Федорчук, студ. ОР "Магістр" Київський національний університет імені Тараса Шевченка, Київ, Україна

\section{ОСОБЛИВОСТІ ДОКАЗУВАННЯ У СПРАВАХ ПРО ДИСКРИМІНАЦІЮ У СФЕРІ ПРАЦІ}

Розкрито особливості доказування у справах про дискримінацію у сфері праці. На підставі аналізу спеціальної літератури, чинного законодавства, міжнародних трудових стандартів внесено пропозиції та рекомендації щодо вдосконалення механізму доказування факту дискримінації у сфері праці. Особливу увагу приділено переведенню тягаря доказування та формуванню "презумпції дискримінації", яка полягає в тому, що у певних випадках, за наявності доказів, які обґрунтовують висунуті звинувачення, тягар доказування відсутності дискримінації може бути перенесений на відповідача. Проаналізовано практику Європейського суду з прав людини про дискримінації у сфері праці й висвітлено основні позиції суду щодо встановлення факту дискримінації. Розелянуто нові види доказів у справах про дискримінацію у сфері праці, а саме, метод ситуціаційного тестування. Запропоновано вимоги щодо умов допустимості доказів у справах про дискримінацію у сфері праці. Окремо звернено увагу на позиції Європейського суду справедливості щодо встановлення фокту дискримінації. Також наведено випадки переведення тягаря доказування на відповідача у випадках, установлених законодавством. Охарактеризовано національний механізм доведення факту дискримінації у сфері праці. Проаналізовано стан національного законодавства та міжнародних стандартів щодо механізму доказування у справах про дискримінацію. Розглянуто нормативно-правове забезпечення, механізми імплементації й інституційну основу забезпечення реалізації державної політики у цій сфері. Особливу увагу приділено зарубіжному досвіду Європейського Союзу, зокрема нормотворчим практикам, для вдосконалення національної концепції розвитку антидискримінаційної стратегії держави.

Ключові слова : дискримінація, доказування, тягар доведення, докази, рівність, міжнародні трудові стандарти.

ВСтУп. Забезпечення рівності й недопущення дискримінації відносять до основоположних міжнародних трудових стандартів. Варто звернути увагу на те, що дискримінація може відбуватися на будь-якій стадії розвитку трудових правовідносин, зокрема: під час прийому на роботу; за встановлення умов трудового договору, зокрема оплати праці; за виплати премій, надання "соціального" пакету; у ході притягнення до дисциплінарної та матеріальної відповідальності; у разі переведень і відсторонення від роботи; у випадку просування по службі; за припинення трудових правовідносин тощо. Доказування фракту дискримінації в суді для забезпечення реалізації права на рівність і заборону дискримінації у сфрері праці викликає ряд проблем на практиці.Так, незважаючи на існування нормативно-правової бази для боротьби з дискримінацією, не визначено належним чином механізм доказування дискримінації. 3 огляду на це, дослідження основних положень щодо доказування дискримінації у сфері праці та пошук шляхів підвищення ефективності реалізації права на захист у сучасних умовах $€$ актуальним.

Проблема дискримінації завжди представляла інтерес для науки трудовго права. Питанню заборони дискримінації у трудових правовідносинах присвячені праці таких учених: А. В. Бородіна, І. В. Лагутіна, Д. А. Паньков, П. Д. Пилипенко, С. М. Прилипко, І. С. Сахарук, О. В. Старчук, І. М. Твердовський, О.В.Тищенко та ін.

Метою статті $є$ визначення особливостей процедури доказування факту дискримінації у сфері праці та внесення пропозицій щодо вдосконалення механізму доказування у справах про дискримінацію.

ВИКЛАД ОСНОВНОГО МАТЕРІАЛУ. ПриНциП РіВНОправності у сфері праці забезпечує рівний доступ до праці й рівні можливості щодо реалізації права на працю. Він не допускає проявів дискримінації у сфері праці. Конституція України закріплює положення про те, що громадяни мають рівні конституційні права і свободи та рівні перед законом (ст. 24) [1]. За загальним правилом, яке закріплене у ст. 81 ЦПК України, кожна сторона має довести ті обставини, на які вона посилається як на підставу своїх вимог або заперечень. У справах про дискримінацію позивач зобов'язаний навести фактичні дані, які підтверджують, що дискримінація відбулася. У разі наведення таких даних доказування їх відсутності покладається на відповідача [2]. Зміни до ЦПК були внесені відносно нещодавно та не повною мірою дозволяють захищати трудові права працвників, але вони вдосконалили механізм доказування у справах про дискримінацію. 